\title{
THE OTHER SIDES OF HISTORY
}

\author{
Flannery Burke
}

Saint Louis University

In March 2015, three teachers, nine international secondary students, and I stood in the cold and wet of early spring looking at the St. Louis Gateway Arch on the other side of a short fence. We had spent the better part of an hour trying to get to a parking garage that would accommodate our van and the rest of the hour looking for a path to the Arch. Now, we could see our goal, and only the fence stood in our way. One of the teachers worked locally and had sacrificed a day of her spring break to tour a portion of the city with us. She and I felt embarrassed. Our city's foremost tourist attraction was almost inaccessible due to highway construction and, she noted, not a single sign had pointed us-or others we encountered-in any useful direction once we found parking.

Two of the teachers had accompanied the students from northern New Mexico, where they and the students worked and lived at the United World College-USA. They had all come, at my invitation, to investigate what I called the "roots of Ferguson." Although the students represented nine different countries, they had followed the news closely following the shooting of Michael Brown by a police officer in August 2014. I had told the teachers that visiting the city would be a deep education in American race relations and that Ferguson was part of the greater St. Louis metro area. No doubt they were wondering just what we were doing almost a dozen miles from the site of Brown's death. Stymied by the construction, the lack of signs, and my own insecurity about the endeavor, I was beginning to wonder myself. Did everyone really need background in the history of the city first? Should I even have taken on this project? While I fretted, a student said, "We could climb the fence." There were no signs forbidding it. We made it to the other side. 
This article outlines how I came to be standing at that fence, what resulted from my time with the international students who visited St. Louis, and the promises and pitfalls of mindful integration of history and civics education in experiential learning. While students demonstrated increased engagement and depth of knowledge following their visit, I felt that they had not fully grasped the nuances of historical and civic thinking that I had intended the trip to teach. My pedagogical challenges exemplify many of the obstacles facing instructors grappling with projects that address contemporary racism and its history. These include: mastering interdisciplinary scholarship; engaging in personal, classroom, and community reflection; negotiating gaps between scholarly knowledge and current media coverage; and accepting the enormity and complexity of an issue like racism. Such roadblocks can prove discouraging to history and civics instructors, even ones dedicated to open and thoughtful conversation about difficult issues. As a whole, I found that civic thinking came no more naturally than historical thinking for students and that integrating the two required more attention and more aspects of experiential learning than many instructors assume. The article concludes by addressing how, despite such challenges, student learning ultimately encouraged me to persevere in the project.

\section{The History Side}

My side of this story begins in a common premise of history education. For over a hundred years, historians have insisted on the innate connection between learning history and civic participation. "Preparing citizens" served as the motivation for U.S. institutions committed to history beginning at least as early as 1892 with the National Education Association's Committee of Ten and continuing through the more recent AHA Tuning Project and the C3 Framework for the Social Studies. ${ }^{1}$ Contemporary events

\footnotetext{
1 The 1892 History, Civil Government, and Political Economy Conference of the Committee of Ten contended that the study of history and civics
} 
often serve as the inspiration for teachers who try to reveal the relevance of history to civic participation. Students, with teacher guidance, inquire into the roots of present-day circumstances, use the field of history to understand the issue under investigation, research more deeply, communicate their findings, and take action in response to their original question. Each step is an active one: from asking questions, to seeking solutions through guided research, through drafting a letter or a speech, to making a decision about how to be a national and global citizen.

The process does not always go smoothly. Teachers may lack adequate knowledge. Schools may lack the resources for a deep investigation. Students may struggle with the speaking and writing skills necessary to convey what they have learned. And there is always the clock. By tomorrow, student (and teacher) interest may have moved elsewhere, and writing a letter to one's city council representative or mapping a possible bus route or sharing news about a new health clinic in town falls by the wayside as teachers struggle to cover content and students juggle competing demands on their time. Beyond such logistical challenges are methodological

"counteract a narrow and provincial spirit; ... and that they assist [the student] to exercise a salutary influence upon the affairs of his country." ("Report of the Committee on Secondary School Studies with the Reports of the Conferences," Government Printing Office, Washington D.C., July 9, 1892, 167). The American Historical Association Committee of Seven in 1898 took as a given that "one of the chief objects of study is to bring boys and girls to some knowledge of their environment and to fit them to become intelligent citizens," and that the study of history best accomplished that aim. See The Study of History in Schools, American Historical Association Committee of Seven, 1898 at: https://www.historians.org/about-aha-and-membership/ aha-history-and-archives/archives/the-study-of-history-in-schools; College, Career and Civic Life (C3) Framework for Social Studies State Standards, https://www.socialstudies.org/c3; AHA Tuning Project, https://www. historians.org/teaching-and-learning/tuning-the-history-discipline. Also see the Bradley Commission Report on History in Schools, 1987, at http:// www.nche.net/bradleyreport, and Gary Nash, Charlotte Crabtree, and Ross E. Dunn, History on Trial: Culture Wars and the Teaching of the Past (New York: Vintage, 2000). 
ones. Assessing evidence, corroborating sources, assembling timelines, and constructing narratives all have their place in historical study and civic participation, but students do not intuit the connections without guidance, and guidance requires time, skill, and knowledge. In short, the connection between civics and history education might not be as natural or as self-evident as historians have, for the past hundred years, commonly assumed.

As I began the Fall 2014 semester in my Historian's Craft class, however, I still considered history and civics to be natural allies, joint teachers of future citizens. ${ }^{2}$ The class is part of the major at Saint Louis University, a Jesuit institution dedicated to preparing "men and women for others." Instructors of the course endeavor to introduce history majors and minors to the fundamentals of historical thinking and research. The class encourages students to take what Keith Barton and Linda Levstik have called the academic historian's "analytical stance." I particularly emphasize the skills of context, change over time, causality, contingency, and complexity. ${ }^{3}$ A close cousin of these skills is periodization, and in this semester I had included Ta-Nehisi Coates's "The Case for Reparations" on the syllabus to prompt a conversation about why we so rarely address redlining, housing segregation, and inequitable lending practices in discussions of the U.S. Civil Rights Movement. Prior to each class session, students completed a quick, written response on a shared document in answer to a

2 Keith C. Barton and Linda S. Levstik, Teaching History for the Common Good (Mahway, NJ: Lawrence Erlbaum Associates, 2004; Taylor \& Francis e-Library, 2008); Peter Levine, We Are the Ones We Have Been Waiting For: The Promise of Civic Renewal in America (Oxford: Oxford University Press, 2013); Meira Levinson, No Citizen Left Behind (Cambridge: Harvard University Press, 2012).

3 Barton and Levstik, Teaching History for the Common Good, 6-7; Thomas Andrews and Flannery Burke, "What Does It Mean to Think Historically?" Perspectives, January 2007, https://www.historians.org/publications-anddirectories/perspectives-on-history/january-2007/what-does-it-mean-to-thinkhistorically. 
question. The question for the Coates essay asked students: Why do so many history textbooks end their discussions of the Civil

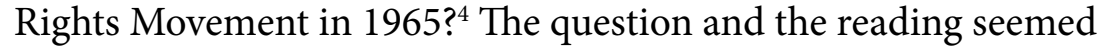
like easy entries into a conversation about connecting the past with the present and historical analysis with civic participation.

Nonetheless, I was more unsettled than I would have expected of myself when Michael Brown was killed and sustained protest began in and around Ferguson. I pondered my responsibilities. What was appropriate civic action in this circumstance? How much attention in class should I give the protests? What if students didn't want to talk about it? How would I cover the material that I already had planned? My class, composed entirely of white students, avoided eye contact when I suggested at the semester's start that conversation might sometimes get heated given present events. They steadfastly bypassed contemporary analogies for the first month of class. Connecting current events to history came easily to me but remained opaque, even a little frightening, to my undergraduates.

I felt a calmer atmosphere after I casually introduced the findings of civics education scholar Diana Hess. Hess argues that secondary school teachers who conceal their political preferences risk modeling apathy for students. ${ }^{5}$ For my own classes, I said, I followed her advice by maintaining a respectful environment for all political opinions but sharing my own when I felt them to be relevant. One student, a double history-political science major, said that he had observed just the phenomenon that Hess describes, even among his fellow political science majors. Another began regularly wearing relatively tasteful $\mathrm{t}$-shirts critical of President Obama. All students began participating more. I felt that I had applied an aspect of civics education successfully and created greater space for conversation and expression in the classroom.

4 Ta-Nehisi Coates, "The Case for Reparations," The Atlantic, June 2014. 5 Diana Hess, Controversy in the Classroom: The Democratic Power of Discussion (New York: Routledge, 2009). 
Then, in early October, just as students began to relax, Vonderrit Myers Jr., the son of a Saint Louis University employee, was shot and killed by an off-duty police officer working as a security guard in St. Louis. ${ }^{6}$ Following Myers's shooting, a group of activists occupied part of the Saint Louis University campus. ${ }^{7}$ At that point, I decided to draw the connection between history and civics more overtly in class.

The occupation seemed like an excellent teaching moment. A current event, right on campus, closely tied to the international media attention that the city had received since Brown's death, seemed to beg for a conversation. Moreover, the occupation overlapped with our reading of Coates's essay. Because students were still learning the "historian's craft" and had not been inclined to raise current events, I drafted a question for them. I asked students to address the question: "Why has there been sustained and vigorous protest following Brown's shooting?" In addition to the Coates article, I gave students the added option of examining Colin Gordon's website, "Mapping Decline," which describes and explains segregation in St. Louis. ${ }^{8}$ My intention was to direct students to a broader context for Brown's shooting, the protests, and the campus occupation. I did not ask students to memorize the events described in "The Case for Reparations" or the series of changes described on Gordon's website. Rather, I wanted students to use the sources to build their own interpretations of presentday events as they actively did history through class conversation and writing for our class GoogleDoc. ${ }^{9}$

\footnotetext{
6 Fred Barbash and Abby Phillip, "Fatal shooting of 18-year-old by off-duty police officer ignites protests in St. Louis," Washington Post, October 9, 2014.

7 Stefan Bradley, Jonathan Pulphus, and Joshua Jones, "A Scholar's Unforseen Connection and Collision with History," The Western Journal of Black Studies 39 (Winter 2015): 273-280.

8 Colin Gordon, "Mapping Decline: St. Louis and the American City" http:// mappingdecline.lib.uiowa.edu/.
}

9 For a somewhat similar approach, see David Neumann, "Solving Problems 
I did not ask students to explain the cause of the shooting, for which we did not yet have any evidence aside from newspaper articles and rumors. Rather, I wanted students to identify the larger historical context for the protests, an activity consistent with the historical thinking skills at the heart of the class. My emphasis on immediate, mid-range, and long-term causes put a finer point on causality and periodization and would preempt (I hoped) an extended conversation of both slavery and the immediate circumstances of Brown's death. I wanted our emphasis to stay on mid-range causes, like red-lining, which had been the original topic of the class.

While I did not assign student work reflecting their responses to the discussion, as an instructor I felt students relax over the course of our conversation. Because all my students were white and had not introduced contemporary events in class themselves, I expected hostility to the topic. I did not encounter any, but I did feel like students were apprehensive that they might "say the wrong thing." I had told them in advance that we were going to apply all the skills we had reviewed so far: seeing an issue from more than one and more than two perspectives; applying the ideas of context, change over time, causality, contingency, and complexity; citing evidence to support our positions and conjectures; and distinguishing between primary and secondary sources. I regularly repeated (for my own benefit as much as for theirs) that historical analysis has the capacity to defuse tense situations and build capacity for mutual understanding by draining issues of clouding emotion and providing room for analysis.

As students did the work, I think that they lost some of their anxiety. Some were from Chicago, the center of Coates's investigation of redlining, and they spoke with eagerness about the neighborhoods that Coates describes. They wanted to know more about the role of Latinx communities in redlining and white flight.

by Creating Problems: Building Coherence in History Through Inquiry," Teaching History 36, no. 2 (2011): 83-96. 
Once I mentioned some local events that may have contributed to the protests, such as conflict over school accreditation in St. Louis City and North St. Louis County schools, areas with majority African American populations, they were able to add to our timeline other events such as the 2012 death of Trayvon Martin and the 2013 neutering of the Voting Rights Act. They seemed relieved to assemble a timeline of events that included the Civil Rights and Voting Rights Acts as well as Brown v. Board of Education and the Selma march. They made a list of causes, just as they had done with U.S. entry into World War I and Cherokee Removal. In the same way that we might call the assassination of Archduke Franz Ferdinand the "triggering event" of World War I, we isolated the shooting and death of Michael Brown as a breaking point in a much longer chain of events. The students were doing history, just as they did history when discussing other less-sensitive subjects, and the work was the same. They were expanding their understanding of the events. Among these were new pieces of knowledge that I provided, such as: "There are ninety municipalities in the county of St. Louis." They made new observations, such as: "How we draw the boundaries of school districts seems to make a big difference." Some expressed resigned sentiments such as: "There's nothing we can do, especially if we're not from here," and "St. Louis is really messed up." I saw such observations and feelings as a product of the historian's analytic stance as well as an open and generally respectful conversation, and I thought that I did well in remaining calm during what I had feared would be tense exchanges. Doing the work of history was an activity familiar to students, and applying their historical skills helped students distance themselves emotionally from a highly charged topic.

10 These statements are drawn from my memory and are not direct quotes. 


\section{The Civics Within History}

History grounded my work with my undergraduates, but, with the exception of my brief mention of Hess's work, civics did not. Although I had held many conversations with civic education specialists in my work for other projects, including the $C 3$ Framework, I was still inclined to take history's value to civics for granted. ${ }^{11}$ "Of course students will apply the same critical thinking skills to the social media platform Yik-Yak that I have taught them to apply to primary sources," I thought. ${ }^{12}$ "Of course students will understand that an event happening in the present-be it a new Metro line or a conflict between civilians and police-is a product of immediate, mid-range, and long-term causes." ${ }^{3}$ "Of course we can all learn from history how to suspend some of our own ideological fervor when weighing a contemporary issue, even one as fraught as racism." ${ }^{14}$ "Of course we ask ourselves what action would be for the common good." 15 "Of course we consider the fact that there will be far more than one and even far more than two perspectives on any given contemporary issue." 16 "Of course

\section{See College, Career and Civic Life (C3) Framework for Social Studies State Standards http://www.socialstudies.org/c3. \\ 12 I had not yet read information from the Stanford History Education Group on how students respond to online information. See, for example, Sam Wineburg and Sarah McGrew, "Why Students Can't Google Their Way to Truth," Education Week, November 1, 2016, http://www.edweek.org/ew/ articles/2016/11/02/why-students-cant-google-their-way-to.html.}

13 I draw the language of "triggering events" from a teacher profiled in Sam Wineburg, Historical Thinking and Other Unnatural Acts: Charting the Future of Teaching the Past (Philadelphia: Temple University Press, 2001), 167.

14 In retrospect, I find this assumption extraordinarily naïve, but I had only just begun to explore resources about implicit bias such as Harvard's Project Implicit; https://implicit.harvard.edu/implicit/. Facing History and the News Literacy Project later tackled this issue directly in their Facing Ferguson lesson, available here: https://www.facinghistory.org/resource-library/facingferguson-news-literacy-digital-age/introduction-unit.

15 Barton and Levstik, Teaching History for the Common Good, 34.

16 David Wrobel, "Historiography as Pedagogy: Thoughts about the Messy 
solutions will not be obvious to us. When have they ever been in the past?"17 It did not occur to me that I had to spell out each one of those connections between historical understanding and civic participation. After all, we had been practicing the skills of doing history every day. We had just applied those skills to a contemporary event. Students had just expressed (or so I thought) some of those very connections. I assumed that we hardly needed to outline how historical analysis can aid civic action. I did not see the oversight as a major flaw in the discussion. In fact, I did not see it as an oversight at all.

\section{The Experiential Side}

The campus occupation ended after a series of discussions between occupiers and the university president. The president, Fred P. Pestello, was in his first year and had already stressed the need for a renewed commitment to the university's Jesuit mission. He noted during and after the discussions that many of the occupiers' requests-bridge programs with area schools, more resources for African American studies, and a stronger relationship with the area's communities of color-were already priorities of his administration. The occupation ended cordially with a set of shared commitments to the university's future called the Clock Tower Accords. ${ }^{18}$ No property damage occurred. None of those involved in the occupation, some of whom were Saint Louis University students, were arrested, tear gassed, or otherwise harmed. Former Attorney General Eric Holder later called Pestello's handling of the situation "nothing short of exemplary." 19 Nonetheless, some families of students expressed

Past and Why We Shouldn't Clean It Up," Teaching History 33, no. 1 (2008):

3-11.

17 Wrobel, "Historiography as Pedagogy," 3-11; Barton and Levstik, Teaching History for the Common Good, 85-86.

18 Clock Tower Accords, https://www.slu.edu/about/key-facts/diversity/ clock-towers-accords.php.

19 Koran Addo, “Attorney General Eric Holder praises SLU president for 
extreme criticisms of the occupation, and I heard rumors that some parents had withdrawn their children from the university. ${ }^{20}$ SLU is a tuition-driven university, and I was concerned that the university would be negatively affected and that relationships with the surrounding community would suffer. "If only," I worried, "I could do something."

Later, I remembered that history is something that I do. Was there a way to get more students interested in doing the kind of history my undergraduate students and I had done when discussing Coates's essay? Wasn't that connecting the past with the present? Wasn't that doing history for the common good? Wasn't that what history teachers did? Maybe, I thought, we could even attract some students to the university because of how we had historicized the events on campus.

My musings were driven by two pivotal moments in my education. First, I'm an enthusiastic alumna of the United World College-USA, a two-year, international high school for students usually aged 16-19, located in Montezuma, New Mexico. The school is one of a consortium of seventeen campuses located all over the world and has its origins in the same kind of experiential learning employed in Outward Bound programs. Each campus hosts students from over eighty different countries to further the UWC mission of fostering international peace, understanding, and sustainability. ${ }^{21}$ The mission is intended as a lifelong endeavor, and I view myself as a UWC-er still, although I graduated years ago. Second, in 2013-2014, I served as a Fulbright Roving Scholar in Norway. Rovers visit high school English classrooms across the country over an academic year. ${ }^{22}$ I visited almost fifty different schools and spoke with thousands of Norwegian students about

handling of campus protest," St. Louis Post-Dispatch, November 6, 2014.

20 Bradley, Pulphus, and Jones, 273-280.

21 The United World Colleges' mission is described at: www.uwc.org. Its foundations in experiential education are described here: "What is experiential education?" at: http://www.aee.org/what-is-ee.

22 The Fulbright Roving Scholars program is described at: 
American culture. I got much quicker on my feet and learned to adjust to a wide range of student abilities, last-minute schedule changes and technological difficulties, and my own shortcomings as an instructor. The experience increased my comfort working with secondary school students and also gave me an opportunity to visit the UWC in Norway, the Red Cross Nordic United World College. In conversation with the headmaster and his family, I was reminded of my own resolution following my graduation from UWC to bring the spirit of the school to my own country, the United States.

Inspired by my own UWC experience, my recent work as a Roving Scholar, and my discussion with my Historian's Craft class, I began thinking about how UWC students themselves might have an opportunity to investigate St. Louis and the racial segregation that had contributed to the Ferguson protests. The United World College curriculum requires students to complete a Project Week in lieu of spring break each year, and through the UWC alumni coordinator I invited a group of students to come to St. Louis for Project Week. My plan was to expand the 75-minute lesson that I had done with my university students to a weeklong "project." Students would do history for a week and discover, I thought, how the Ferguson protests had emerged. I assumed that the implications of the history we would learn would be obvious.

UWC-USA accepted the invitation, and nine students, both first- and second-years, of multiple races, and from countries in North America, eastern Europe, northern Europe, southern Asia, the Caribbean, western Africa, and the Middle East participated. ${ }^{23}$ Student and UWC Project Week funds covered travel and food expenses. The group drove to St. Louis from New Mexico, so that

https://fulbright.no/grants/grants-to-norway/us-scholars/roving-scholars/. 23 I would like to be more precise in describing the students, as several of their insights and mine came from the intersection of their previous experiences with the events that occurred in St. Louis, but to protect their privacy I have chosen not to identify students by gender, race, or national origin. 
local travel was covered as well. I contacted my fellow faculty, area high school teachers, a local organization called EdPlus that provides curriculum services to St. Louis County public schools, a local artist who had completed work with community input in North St. Louis, an activist I knew through other UWC-ers and who had been a regular protester in Ferguson, and a legal observer of the protests who I knew through our neighborhood elementary school. Those whom I contacted connected me with another area activist and with Amy Hunter, then the Director of Racial Justice at the Metro St. Louis YWCA, whose Tedx talk, "Lucky Zip Codes," proved remarkably timely for St. Louisans seeking to understand Ferguson's wider context. ${ }^{24}$

The curriculum for the week proved to be an ongoing negotiation among the faculty advisors, the students, and those who had offered their time for the project. Students had a Google folder of readings, documentaries, and other resources compiled by their advisors and some of our speakers. I also contributed to these discussions. Few students did any of the reading before arriving in St. Louis, but almost all of the students (usually with some prompting from their advisors) completed the reading or viewing by the day it was relevant to our activities. In fact, the list of readings grew as the students, their faculty advisors, the people with whom we were meeting, and I added to it. ${ }^{25}$

Student independence and leadership flowered over the course of the week. Students toured the city with a member of the North St. Louis Catholic Worker community, an artist who had completed a public work addressing racism, and me. They toured the St. Louis Art Museum with a representative of the Anti-Defamation League. They observed a protest, visited a North County school with a predominantly African American student population, and met with students and faculty at Saint

24 Amy Hunter, "Lucky Zip Codes," TEDxGatewayArch https://www. youtube.com/watch? $v=\mathrm{gdX} 8 \mathrm{uN} 6 \mathrm{VbUE}$.

25 See the appendix for books, articles, and video resources. 
Louis University. They heard one of their faculty advisors and me argue about a news story and its reliability. At the students' request, at the last minute, I also approached a police officer, who graciously agreed to come to the house where they were staying for a conversation. Throughout, I observed that when I sat back and let the students ask the questions (and invite the speakers!), adults responded to them as if they were adults themselves. It was affirming to see how experiential learning allows students to lead their own learning. ${ }^{26}$

Students leading their own learning did not mean that I was not teaching history. By the end of the week, students were regularly saying: "It's in the bricks and mortar." ${ }^{27}$ I had taught them the phrase, and it had become a shorthand for redlining, racial covenants, and gated communities that built racial segregation into the landscape of the city of St. Louis. Students also had rapidly picked up on the lesson that I had tried to teach my undergraduates: that Brown's shooting was only the proximate cause of the protests and that long-term and mid-range causes were equally if not more important for the students to consider as they began to turn their thoughts toward solutions. One student also remarked to me "You sure know a lot of historians," which I took as a sign that historical thinking had led the week's activities.

The students were not the only ones learning. Our first day had been a sort of St. Louis history boot camp that began with scaling that sad little fence. The day included a discussion of the Dred Scott decision; a discussion of the effects of highways on the urban landscape; visits to the site of the now-demolished PruittIgoe public housing project; the Shelley house, the focus of the 1948 Shelley v. Kraemer Supreme Court decision, which prohibited

26 See "What is experiential education?" http://www.aee.org/what-is-ee. 27 For the value of teaching history from places, see David G. Vanderstel, “"And I Thought Historians Only Taught,"” OAH Magazine of History 16 (Winter 2002): 5-7; Beth M. Boland, "Historic Places: Common Ground for Teachers and Historians," OAH Magazine of History 16 (Winter 2002): $19-21$. 
court enforcement of racial covenants on real estate; and the Arch, which activist Percy Green had occupied in 1964 during its construction to protest discriminatory hiring practices. As a result of this crash course, students were well versed when they met protesters, residents of North St. Louis County, and the speakers with whom I had arranged visits. I watched many of my colleagues and other adults with whom students spoke boost the level of discussion as they realized how well educated the students already were and how curious they were to learn more. Was Ferguson an example of history repeating itself or rhyming, asked one student, who credited the idea to Mark Twain. Because most of the students were from outside the United States, they also frequently asked unexpected and insightful questions about daily life that Americans in St. Louis might take for granted. And because I had recently taught outside the United States myself, I was able to alert speakers to qualities of the city and nation-such as public school funding through property taxes or the identification of residents by race in the U.S. census-which might be opaque or confusing or even shocking to non-Americans. ${ }^{28}$ Such questions from the students educated those with whom students met about how the international community perceived Brown's death, Ferguson, and American race relations more broadly.

I was learning too. I began to articulate some of the issues of race in the region more concretely. After the visit, I was able to explain more clearly how individual municipalities had incorporated specifically to exclude African Americans, a process contributing to the patchwork of city governments that my SLU undergraduates had identified. I also learned aspects of the history of the region that I was surprised that I hadn't known previously. Ferguson was

28 The sensitivity to "self-understanding" and "understanding of others" that emerges from international instruction and "historical consciousness" is well described in Sabine N. Meyer, "Transcending Intellectual Nationalism: Teaching U.S. History in German Universities," Journal of American History 96, no. 4 (2010): 1094-1099. 
once known as a "sundown town," meaning African Americans could work in the town but had to leave by sunset. I did not learn about "sundown" Ferguson from archival or library research or even from James Loewen, the author of Lies My Teacher Told Me as well as Sundown Towns: A Hidden Dimension of American Racism. ${ }^{29}$ Rather, I learned about it from a woman observing a protest whom students questioned eagerly for more information. It was just one of the many moments that caused me to think about how experiential learning can activate historical knowledge that allows students to address contemporary controversies effectively.

The student learning also stuck. Although my university's IRB office did not allow any formal survey of the students' experiences, I was able to follow up with them informally. Two students participated in a podcast about their Project Week experience when they returned from St. Louis. Two students chose to study race relations in the United States for their Extended Essays, a summer research project required for the UWC's International Baccalaureate curriculum. Two were considering describing the week for their college application essays. When I reminded them of what I meant by "reading the landscape," two mentioned that they had noticed for the first time in their hometowns places and public transportation systems unwelcoming to people of color. One student applied and was admitted to Saint Louis University. In all, the experience met virtually all my initial goals for the project and validated my confidence in experiential learning for history instruction.

\section{The Civics Side}

None of my goals, however, had explicitly addressed civic learning, and the flaws in the project emerged from that oversight.

29 James W. Loewen, Lies My Teacher Told Me: Everything Your American History Textbook Got Wrong (New York: The New Press, 1995); James W. Loewen, Sundown Towns: A Hidden Dimension of American Racism (New York: The New Press, 2005). 
Because I assumed that history and civics would naturally connect, I did not make my civic learning goals overt in the same way I did my history learning goals. I was unaware of work that trained students in how to participate in the civic realm-how to speak at a public school board meeting, for example. ${ }^{30} \mathrm{I}$ had not delved deeply into the literature on deliberation and generally used the term to describe anything that was not acrimonious discord. ${ }^{31}$ Given the experiential learning that underlies UWC education, however, a clear conversation about our civics goals should have been part of our preparation. We never engaged in measured reflection about why we were engaged in the project. We never considered the advantages and disadvantages of potential policy responses to the Ferguson protests or to state violence. While our historical understanding of causality and context grew, our civic understanding of how to frame the variety of perspectives that we were encountering languished.

For example, I had initially envisioned students volunteering at area schools. I cared less about the students "helping" than about the students witnessing the vast disparity that exists in St. Louis public schools, a product of a system that funds schools through property taxes. Few St. Louisans expressed surprise when conversation shifted, sometimes within the same sentence, from the Ferguson protests to area schooling. Immediately after her son's death, Lesley McSpadden, Brown's mother, expressed her grief in part by asking: "Do you know how hard it was for me to get him to stay in school and graduate? Do you know how many black men graduate? Not many. Because you bring them down to this type of level." ${ }^{32}$ The school district from which Brown graduated,

30 Ben Kirshner, Youth Activism in an Era of Education Inequality (New York: New York University Press, 2015.)

31 I am drawing my definition of "deliberation" from the work of the Kettering Foundation; see, for example, David Mathews, Naming and Framing Difficult Issues to Make Sound Decisions (Dayton, OH: Kettering Foundation, 2016).

32 KMOV-TV, August 2014. 
Normandy, had lost its accreditation in 2013. The decision provoked a hostile and racially charged public meeting in Francis Howell, a predominantly white district designated to accept the Normandy students under a state law. Normandy's accreditation and the state law generally received only local attention until the Ferguson protests began. Then, nationally, many learned of the law and the public forum in an article by journalist Nikole Hannah-Jones in December 2014..$^{33}$ Excerpts from the school board meeting aired on a July 2015 episode of "This American Life" that showcased Hannah-Jones's article. ${ }^{34}$ To me, then, getting the students into area schools was key to the whole project. How would students understand mid-range causes and how would they recognize the depth of the region's frustration if they only examined community-police relations?

The faculty advisors, however, were very wary about the students appearing as volunteers. They had rejected those students whose applications for the Project Week stressed "helping." Rather, they wanted the students to witness and learn. ${ }^{35}$ The advisors and students had been inspired, I think, by a visit to the UWC campus of a group of activists who had been very involved in the Ferguson protests. I understood their reluctance to have students volunteer, but I feared that students would be sitting around in between brief conversations with locals. And I was genuinely anxious that students would be arrested (and for those non-Americans, risk deportation) if they were perceived as participating in a protest. We were working so quickly, however, that the students' faculty

\footnotetext{
33 Nikole Hannah-Jones, "School Segregation: The Continuing Tragedy of Ferguson," ProPublica with The New York Times, December 19, 2014 ; https://www.propublica.org/article/ferguson-school-segregation. 34 "The Problem We All Live With," This American Life, broadcast July 31, 2015. The episode had not yet aired at the time of the UWC students' visit. 35 Reflection is a key part of experiential education, an educational philosophy with strong roots in the work of one of the United World College founders, Kurt Hahn. See, for example, "What is experiential education?" http://www.aee.org/what-is-ee and http://www.kurthahn.org/writings/.
} 
advisors and I never deliberated as to our shared values or our desired outcomes for the week or even what action we wanted students to take. Had we done so, we might have realized that the students and their advisors were framing Brown's death as an example of state violence whereas I saw it as a product of longterm racial segregation and inequality.

Similarly, my reactions to emotion and its value varied dramatically from those of the students. I hadn't visited the memorial to Mike Brown at the Canfield apartment complex where he was shot because I didn't want to sentimentalize what I considered an issue that required serious analysis. Nor did I want to objectify African Americans in North St. Louis County. As I had told my undergraduates, a benefit of history is that it can "drain" events of clouding emotion. The students, however, really wanted to go to the memorial. And one of our speakers even asked later: "I assume the students have already made the pilgrimage to Canfield?" I didn't even know the memorial's location, which indicated to me just how shallow my own knowledge of the "bricks and mortar" of the city actually was. My historian's analytical stance had only gotten me so far in understanding race and segregation in St. Louis. ${ }^{36}$

In fact, after the most emotional of their investigationsthe visit to Canfield and our observation of a protest-students told me: "This is history." Knowing that such places and events had been headline news for months made the significance of the events palpable to students in a way that I had not considered. It had, if anything, enhanced their analytical stance. Students observed how cameramen converged on a conflict between a motorist and protesters such that the conflict, its drama, and the size of the crowd were exaggerated. In effect, they "sourced" their observation in real time, noting how the medium of their information affected the content of their information. Students not

36 On the limitations of the historian's "analytical stance," see Barton and Levstik, Teaching History for the Common Good, 44-125. 
only actively did history; they also felt that they were participating in the making of history by witnessing such encounters. While I think my reservations about emotion had merit, I also saw how I had almost shut down possible avenues of curiosity for students not yet even in college. If the historian's analytical stance "drains" an issue of emotion, no wonder so many students consider it dry and boring!

In such moments, I attributed any uneasiness or shakiness that I felt to the experiential nature of the project, but upon reflection, I realized that inattention to civics underlay most of my concern. The events that had the greatest impression on the UWC students unfolded in real time, and I could not plan them. The UWC students experienced events more deeply than did my SLU undergraduate students because they experienced those events in the public realm. Had my undergraduates undertaken a similar project, they likely would have felt equally engaged. Had they been so, it's unlikely that our conversation would have been as calm as it was without more deliberative framing. I suspected that most of the UWC students supported the protesters. I very much did not want to insist on any kind of political action on their part, but I did not ask for their political views as we began the project. Nor did I introduce the idea, as I had with my undergraduates, that we could productively share differing political viewpoints with one another.

This oversight emerged most clearly when students met with a police officer. I thought that I had introduced students to many different people with many different perspectives on the topic: black, white, and Latinx people, people who had and had not participated in protests, people who lived in the city of St. Louis and in the much larger county surrounding the city, people who lived in both the north and south of the county, as well as people who had and had not encountered what they considered racially motivated policing. Nonetheless, the students felt that until they spoke with a police officer, they had only heard "one side." And 
even after our conversation with the officer, students said that they were glad that they had heard "from the other side."

Months later when I checked in with the UWC students, I asked what they had meant when they said they heard from "the other side" and explained that the phrase implied to me the idea that there were only two sides to the story. Perhaps because we were in more of a seminar environment, students replied that such thinking was "too dualistic." In this particular case, they said that they were referring to police and citizen protesters, not to black and white residents or to people who did and did not share their views. I was mollified, but the conversation gnawed at me.

With more reflection, I realized that aside from the active steps like querying evidence and constructing narratives that accompany the historian's analytical stance, I had provided few tools to students for pivoting to other stances, ones better suited for civic expression. Even these (the "identify" and "moral" stances outlined by Barton and Levstik, for example) would have been incomplete without conversation about students' positioning of themselves as non-Americans and as moral actors. ${ }^{37}$ When it came time to act-when the students decided to invite one of the speakers - they chose someone from "the other side." They did not ask to speak with a real estate developer or a school superintendent or a county commissioner or any other "mid-range" or "longterm" actor who might have provided an alternate perspective on segregation, who might be equally if not more responsible for the events that had drawn the students to Ferguson in the first place. Had all of us-students, their advisors, and I-had an open and deliberate conversation about our expectations for the week, I might have seen their invitation coming.

I, at least, would have been prepared to raise and address the issues of state violence and segregation as linked, but distinct problems, that likely require different responses from

37 Barton and Levstik, Teaching History for the Common Good, 45-68; 91-109. 
different individuals. One month after the students visited, the Organization of American Historians met in St. Louis, and in a plenary session historian Eric Sandweiss referred to officer Darren Wilson's decision to shoot Brown as "personally unpredictable and historically overdetermined." I wish I'd had that language when hosting the students as they groped toward their own personal responsibility in the modern world and the history that had brought them there. It is possible that what students really meant when they asked to speak with someone "from the other side" was someone from the side of the personal, rather than the historical, from the side of the unpredictable, rather than the side of the overdetermined. They wanted to know how to position themselves, personally, in the sweep of history.

In fact, when I met with them following the project, they had dozens of ideas of next steps for the St. Louis region. "What should the people of St. Louis do?" I asked. "Integrate!" responded one. "Um, how exactly?" I asked. "Whatever worked last time," was the reply, one I had a hard time hearing as anything other than discouraging. Hadn't we spent a whole week on what did not work last time? The students, however, quickly jumped to unite what they had learned about the history of the city and its race relations to what they had found out for themselves about contemporary lines of action. They hardly hesitated to offer suggestions: fund mixed income housing, increase funding for schools where students perform poorly on tests, include recent history in textbooks, take down the gates surrounding gated neighborhoods, end the property tax-funded school systems, target the prison industrial complex for reform, and start conversations among people who "don't want to be involved."

Despite the project's flaws, history had come to mean doing something for this group of students. It meant forming questions, applying historical tools, researching problems in a variety of different sources, communicating findings, and taking action, action that I most certainly had not prescribed. It meant reading the landscape. It meant processing raw emotion into a cogent 
opinion about modern race relations. How they arrived at such bold and far-reaching agendas after my mish-mash of historical lessons and timid caveats cautioning restraint is still astonishing to me. That they did so gives me hope that historians can learn to articulate the connections between our discipline and civic action despite the fact that such work is intimidating and challenging.

\section{Conclusion}

The challenges are substantial. As the footnotes to this article attest, experiential education and probing the connections between history and civics are nothing new. As pleased as I was with the students' enthusiasm following the project, I wondered if it bore repeating. I was unlikely to reach any new major research conclusions; IRB prevented me from publishing many details of the students' reactions; and the work was in addition to my existing teaching and service obligations. Why do this project when there was nothing tangible in it for me, and the benefits to the students were impossible to pin down?

What ultimately persuaded me to persist that day at the Arch was my realization that the obstacles facing us paralleled those that scholars face when discussing racism. The project required integrating findings from historians, political scientists, geographers, and sociologists; identifying those moments that required individual, class, and community reflection; leaving the classroom to read the landscape and talk with members of the community; determining when emotion fed further inquiry and when it shut down participation; and, ultimately, accepting that complex problems do not have quick solutions. In short, the project required thoughtfully and intentionally negotiating those difficult places where history and civics meet.

Following these insights, I began to incorporate what I had learned in my undergraduate Historian's Craft class by explicitly outlining the connections between history and civic action. The class opens with a sourcing exercise that shows students how the 
skills that they apply to historical sources also help them to parse contemporary media. I overtly highlighted those moments when we pivoted from the historian's analytical stance to other stances that engage the past. In a discussion with an area high school teacher whom I invited to meet with the class, I raised Hess's theory about expressing political views in the classroom. At the outset of the semester, we addressed specifically how to facilitate the classroom as a civic space. We returned to the idea in a unit on civics and discussed how we might frame topics such that all parties feel included. We did an entire unit on maps as historical sources and as historical narratives. I offered extra credit to students who visited a place in the city and wrote about reading the landscape. When we engaged in a deliberative exercise about Ferguson, students felt prepared to consider the trade-offs of different policy responses. Every student in the class participated. The topic was difficult, but it was not taboo.

Our class discussion hardly solved all problems. I hold no illusions about what the next generation is up against as it confronts American racism. I do not believe that anyone has all the answers to the thorny problems that St. Louis faces. Indeed, a central lesson of my classroom has become the importance of recognizing a long view and having patience with efforts to overcome the seemingly intractable problem of racism. I would like to say that I arrived at this lesson on my own, but the students taught it to me. We can learn from the young people who are willing to take up the work of connecting the past, the present, and the future even if, as one student commented, "It's going to take a lot longer than we think." 


\section{APPENDIX}

\section{Reading List as Compiled by Faculty and Students}

1. The Pruitt-Igoe Myth Documentary at: http://www.pruitt-igoe.com/

2. BBC spot on the "Delmar Divide" about segregation in St. Louis https://www. youtube.com/watch?v=yeDFnZlBo0A

3. Website accompanying Mapping Decline: St. Louis and the American City http://mappingdecline.lib.uiowa.edu/

4. Article explaining how racism was built into the urban landscape of St. Louis: http://www.dissentmagazine.org/blog/how-racism-became-policy-in-ferguson

5. Amy Hunter's Gateway City Ted Talk at https://www.youtube.com/ watch? $\mathrm{v}=\mathrm{g} 36 \mathrm{ijwr} 3 \mathrm{wc8}$

6. Ta-Nehisi Coates, “The Case for Reparations," The Atlantic https://www. theatlantic.com/magazine/archive/2014/06/the-case-for-reparations/361631/

7. "What MLK can teach Ferguson," Stefan Bradley, http://www.stlamerican. com/mlk/article 47e6e31c-9d9e-11e4-89a0-9307affa27b5.html

8. The Washington Post, "How St. Louis Profits from Poverty" http://www. washingtonpost.com/news/the-watch/wp/2014/09/03/how-st-louis-countymissouri-profits-from-poverty/

9. Audio interview with Michelle Alexander, author of The New Jim Crow: Mass Incarceration in the Age of Colorblindness: http://www.npr. org/2012/01/16/145175694/legal-scholar-jim-crow-still-exists-in-america

10. The Making of Ferguson: http://prospect.org/article/making-ferguson-howdecades-hostile-policy-created-powder-keg

11. Living Apart: How the Government Betrayed a Landmark Civil Rights Law: http://billmoyers.com/2014/05/21/living-apart-how-the-government-betrayed-alandmark-civil-rights-law/

12. Brittney Cooper, "White America's Scary Delusion: Why Its Sense of Black Humanity is so Skewed," http://www.salon.com/2014/12/03/white americas scary delusion why violence is at the core of whiteness/

13. Kara Brown, "Most White People Think Race Played No Factor in Ferguson \& Garner Cases,” http://jezebel.com/most-white-people-think-race-played-nofactor-in-fergus-1668476797

14. Stacey Patton, “In America, Black Children Don't Get to Be Children,” http:// www.washingtonpost.com/opinions/in-america-black-children-dont-get-to-bechildren/2014/11/26/a9e24756-74ee-11e4-a755-e32227229e7b story.html 
15. Kara Brown, "Ferguson: Injustice Still Hurts When You See It Coming," http://jezebel.com/ferguson-injustice-still-hurts-when-you-see-itcoming-1663209747

16. Kara Brown, "This Is Why We're Mad About the Shooting of Mike Brown," http://jezebel.com/this-is-why-were-mad-about-the-shooting-of-mike-brown1619522935/+KaraBrown

17. Brittney Cooper, "In Defense of Black Rage: Michael Brown, Police and the American Dream," http://www.salon.com/2014/08/12/in defense of black rage michael brown police and the american dream/

18. The Ferguson ArtRising (includes writeup of Artivist Elizabeth Vega): http:// temporaryartreview.com/the-ferguson-artrising/

19. Activists offering services for students to fulfill during spring break: https:// www.riverfronttimes.com/newsblog/2015/02/10/alternative-spring-break-aimsto-connect-students-to-healing-efforts-in-ferguson

20. Video of St. Louis Symphony action organized by Elizabeth Vega and Sarah Greisbach: https://www.youtube.com/watch?v=T 7ErkQFduQ

21. National police perspectives at http://www.thisamericanlife.org/radioarchives/episode/547/cops-see-it-differently-part-one 